\title{
Virtual Underground City Osówka
}

\author{
Mateusz Jabłoński, Tomasz Lipecki, Wojciech Jaśkowski, Agnieszka Ochałek
}

AGH University of Science and Technology, Faculty of Mining Surveying and Environmental Engineering, al. A. Mickiewicza 30, 30-059 Krakow, Poland;

e-mail: jablon@agh.edu.pl,lipecki@agh.edu.pl, jaskow@agh.edu.pl, ochal@student.agh.edu.pl

(C) 2016 Authors. This is an open access publication, which can be used, distributed and reproduced in any medium according to the Creative Commons CC-BY 4.0 License requiring that the original work has been properly cited.

Project Riese (German for giant) in the Owl Mountains (Góry Sowie), located in Lower Silesia, was the largest mining and building project of Nazi Germany. The construction work was done by forced laborers, POWs, and prisoners of concentration camp Gross-Rosen. Many of them lost their lives. The whole project was kept in secret, even the beginning of the construction work is unclear. The purpose of Riese remains uncertain because of lack of documentation, it is still rather a hypothesis than a fact. The only verified information is that the project was abandoned at the initial stage due to the approach of the Red Army. Before that, Nazis put a lot of effort to hide all information about Riese. Today, we can see how successful these efforts were. Nowadays, six underground structures were discovered in Walim and Głuszyca area: Włodarz (3000 m of tunnels), Osówka (1700 m of tunnels), Sokolec (or Gontów - $800 \mathrm{~m}$ of tunnels), Soboń (740 m of tunnels), Rzeczka (560 m of tunnels), Jugowice (500 m of tunnels) and about $600 \mathrm{~m}$ of tunnels under Książ Castle in Wałbrzych (Aniszewski 2002, Graba 2012). It has been found that many of the tunnels in some structures have a dead end, and there is a theory this might prove that all complexes were supposed to be combined. It is believed that many kilometers of the underground tunnels are still to be discovered (Cera 1998).

The whole area is one of the most popular destinations for treasure hunters and scientists. Nowadays treasure hunters are using not only maps and metal detectors, but also GPRs. Scientists are interested in Riese because of many underground tunnels in various sizes and depth, as well as huge amount of steel which was used to reinforce adits. All these details allow scientists to perform many different types of research. Geophysicists are testing the equipment and methodology in the area of gravimetric, magnetic and GPR measurements. All geophysical measurements need to be put into the coordinate system, local or global. Moreover, to eliminate gravity or magnetic effect of the excavations and steel reinforcements their shape must be known (Porzucek 2013). To meet the needs of scientists, researchers, tourists and museum authorities, authors of this report, with the help of students, performed a full inventory of Osówka complex. It was performed in 2015 and covered all underground and ground objects.

$1700 \mathrm{~m}$ of underground tunnels in the main part of the complex (Museum of Underground City Osówka) were scanned, together with $130 \mathrm{~m}$ of Sztolnia Wodna (from Polish water adit) and two ground objects: Siłownia and Kasyno. These two objects are supposed to be nuclear energy plants and Hitler's headquarters or command headquarters (Cera 1998). During measurements, laser scanner (Faro, Focus 3D), tachymeter (Topcon, OS103) and GPS receivers (Topcon, HiperPro) for georeferencing were used.

The main scientific importance of the study is a unique data set that was collected during this research. Afterwords, geometrical relations between objects of Osówka complex were analyzed. The previously supposed course of the Sztolnia Wodna and its destination was revised. Moreover, the possible lift shaft connecting Siłownia and underground part of Osówka was confirmed. The report presents location of objects in relations to 
each other which was not previously verified in research or verified in the other ways. Although, it is possible to do geophysics measurement on unexplored field, data from researches provides possibility of introducing excavations height and size amendments.

Another inventory result is a virtual museum, available from $1^{\text {st }}$ April for everybody on Museum of Underground City Osówka website (www. osowka.pl). The user can virtually explore the whole complex, including places where visitors are not allowed. During measurements, flooded adits have also been inventoried: the ones in the museum and in Sztolnia Wodna (entrance collapsed in November 2015 and the whole adit is in danger of collapsing). Inventory also included Siłownia (firstly, water has been pumped out to allow measurements in the staircase and alleged lift shaft). Another inaccessible place available during the virtual tour is shaft connecting the forest near Kasyno to the undergrounds. The virtual tour allows also measuring selected surface or distance between chosen points and checking coordinates or height in a particular spot. The user can generate a link to a screen which interests him and upload it to any website.
It must be said that even sharing this amount of data doesn't equate to possibility of conducting research and measurements in appointed spots. Project Riese is located on the land belonging to the local government, individuals and National Forests (the majority of it). Before taking any actions, area manager must give his permission. It is strictly enforced since the whole "golden train" story in July 2015.

Research for the article was funded by statutory research of the Department of Mining Areas Protection, Geoinformatics and Mining Surveying (AGH University of Science and Technology) no. 11.11.150.195.

\section{REFERENCES}

Aniszewski M., 2002. Podziemny świat Gór Sowich. Oficyna Wydawnicza Aniszewski, Kraków.

Cera J., 1998. Tajemnice Gór Sowich. AURH Inter Cera, Kraków.

Graba D., 2012. Tajny projekt III Rzeszy FHQu „RIESE”. Wydawnictwo Technol, Kraków.

Porzucek S., 2013. Wykrywanie rozluźnień i spękań górotworu nad pustkami antropogenicznymi metoda mikrograwimetryczna. Rozprawy, Monografie 297, Wydawnictwa AGH, Kraków. 